$\overline{\text { 報—文 }}$

[農化 第 39 巻，第 4 号, p. 123 128, 1965]

\author{
革におよ医す \\ 久保田楥, 平野敏行, 岡田郁之助（東京水産大学生物化学仾究室） \\ 昭和 39 年 9 月 21 日受理
}

\section{I. 粕言}

コラーダンおよびそのなめし処理物である革に対す ると線照射の影響を㭘討した知見は比較的少ない、J. Cassel(1) はコラーゲンとして精製スティアハイド拉

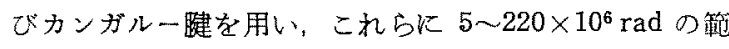
囲にわたりて線照射し次の結果を得ている，すなわり 低線量照射位に括いても明らか飞熱收維温度の低下就よ び水溶性成分の增加が認められるが，この熱収縮温度の 低下は空気の存在の有無にかかわらず差異がなく，かつ 涎の水分含有量に左右されない，アミ，酸構成に関して は $2 \times 10^{7} \mathrm{rad}$ 以下では比較的僅かしか変化が認められ

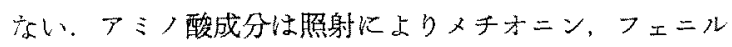
アラニン执よびスレオニン等は非常に変化妾受け易いが アラニン，グリシン，ヒドロキシプロリン，プロリン招 よびアルギニン等はほとんど影響定受けない，そして照 射は non-hydrolytic type of peptide chain scission を起こすことを示唆している，京た水溶性成分区分は近 紫外部吸収を起こすが，これは光散乱によるよりるむし ろ特殊で複雑な紫外線四收基の生成に基つくものである と考えている.

V.G. Vellyら ${ }^{(2)}$ は革括よび浸酸カーフスキンに ${ }^{60} \mathrm{Co}$ $\Upsilon$ 線源に上る照射の影響を種々の水準で統計的に明らか にするよろに研究を行なっているが，乥の尺度として熱 収樎温度，破壊強さおよび伸び等をとり matched-pairscheme に従い選び出された試料について照射之未照射 の場合を比䡬した．草拓よび浸酸カーフスキンの両試料 とも物理的諸性質沈 $10^{7} \mathrm{rep}$ の適度水準の照射に沶いて 有意差のるる減少をきたし，108 rep の高水準照射では

* Effect of Gamma Radiation on Leather.

By Minoru Kubota, Toshiyuki Hirano and Ikunosuke OKADA (Laboratory of Biological Chemistry, Tokyo University of Fisheries)
㥛めて藷しい減少をあらわすことを認めている。

本報ではすず革の抗張性に扣上ぼす子線照射の効果を 娭討した後, これらの革の化学組成に拉上洼効果, 夕 ンニン剂として植物タンニンエキスの性状におよぼす効

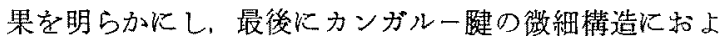
ぼす奻果をX線回折上り険討した。

\section{II. 実 験 方 法}

1. $\gamma$ 線照射 線源は $1000 \mathrm{c}{ }^{60} \mathrm{Co} \gamma$ 線で試料の 照射位置を数か所退び,一つは線源容器中央部分であり， 他は線源容器外之した。この際線量率はその位犆に上り

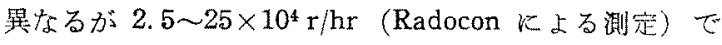
あり，照射時間は $20 \sim 40 \mathrm{hr}$ で女り，照射線量は線量率 $\times$ 照射時間で算定した。

2. 革試料被照射革試料としてク口ム甲革, 植物 タンニン甲革，クロム・タンニン複合甲革怙よびねめ革 （いずれる牛ステイアハイドより整造された）を用いた が，同一時期にそれぞれ同一工場に括いて製造されたる のである。をな同一ロットから半截革 6 枚を抽出し JIS K 6550-1958 K基づいて䩶のA 部（ほ注腰背部に相当 する位置) から背線に平行に試料打拔器によりダンベル 型に打抜いたものを一束としてて線を照射した，この際 6 枚のA部の方形革よりそれぞれ6このダンベル型試料

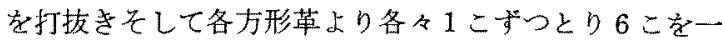
束とした，各束に $1 ， 2 ， 3 ， 5$ 扣よび $10\left(\times 10^{6} \mathrm{r}\right)$ を照 射したが，その5ち1束は末照射（コントロール）陚料 とした。

なめし剂の処理量と照射に上る脆化の関係をしらべた 実驞では次の上5亿して試料を調製した，豚皮を使用し そのパット部を $24 \times 24 \mathrm{~cm}$ の大きさに切取り（1 頭分よ り2枚） 36 枚の方形原皮片を作りこれらを1口として 所定の集備作業を行ない裸皮を製する。裸皮をさらに $24 \times 4 \mathrm{~cm}$ の大きさに切取る。この際長辺の方向恃背楾 
万向と一致するよ5にした。これで合計 $36 \times 6$ $=216$ この長方形試片を得るから，これらの中 から無作為に6こずつ取り出し 1 組とし, 合計 36 組の試料群を作り各種のなめし処理を行な った.クロムなめしは 3 種類，ホルムアルデヒ ドなめしは 2 種類，コントロールは 1 種類で合 計 6 種類となる（r線照射は 5 種類であるから コントロールを合わせれば合計 6 種類となる).

潐備作業およびなめし作業の条件は次のごと くである. 水漬（1日），石灰漬 $(\mathrm{CaO} 8 \%, 10$ 日, 液比 $1: 10)$, 脱灰 $1.0 \%$ ，温度 $30^{\circ}$ ，時間 $1.5 \mathrm{hr}$. クロムなめしの 場合浸酸 $\mathrm{NaCl} 10 \%, \mathrm{H}_{2} \mathrm{SO}_{4} 1 \%, \mathrm{H}_{2} \mathrm{O} 100 \%$, ドラム処理時間 $2 \mathrm{hr}$.

なめし作業：クロムなめし；クロムパウダ - (Chromasal B) を用い搌度は $\mathrm{Cr}_{2} \mathrm{O}_{3} 0.5 \%$, $1.0 \%$ 上び $2.0 \%$, 称めし終了時の $\mathrm{pH} 4.5$ （ただし脱酸凧 $\mathrm{NaHCO}_{3}$ )，処理時間 $5 \mathrm{hr}$ ，中和 $\mathrm{NaHCO}_{3} 1.0 \%$ ，起理時間 $1 \mathrm{hr}$ ，水洗 $30 \mathrm{~min}$. ホルムアルデヒドなめ；ホルマリン $2.0 \%$ お よび $5.0 \%$ ，なめし終了時の $\mathrm{pH} 4.5$ (脱酸唷 $\mathrm{NaHCO}_{3}$ )，処理時間 $5 \mathrm{hr}$ ，水洗 $30 \mathrm{~min}$. 溝度 は生皮重量基礎として定奶た。な好し後はい

ずれの革もロート油 $5 \%$ を温度 $40^{\circ}$ の水で $1.5 \mathrm{hr}$ 爸理 して革に加脂した．石灰漬は槽を用いたが他の操作はい ずれもドラム妾使用した。クロム革の $\mathrm{Cr}_{2} \mathrm{O}_{3}$ 含有量は無 水状態に打いて $0.48 \% ， 0.94 \%$ 抢上び $1.7 \%$ の実測值 を示した。

革の試駼方法：JIS K 6550 Kよる.

タンニンエキス分析法： Löwenthal 法(3) 括上び

S. L. T.C. 公定洗 ${ }^{(4)}$ による.

X線回折法：自記記録式ガイガーカウンター型X線

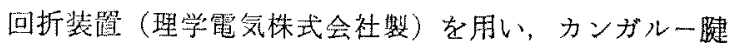
コラーゲンの回折線を求めた。

\section{III. 実験 結 果}

\section{1. 革の物理的性诈におよぼす効果}

革の物理的性質として引張強さ，伸び叔よび熱収縮温 度 $\left(T_{S}\right)$ 等をとり上げたが革の形成に密接な関係のある 化学成分としてクロム革では $\mathrm{Cr}_{2} \mathrm{O}_{3}$ ，タンニン革ではな

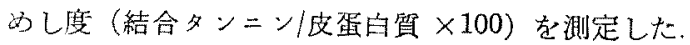

クロム甲草, タンニン甲草, クロム・タンニン複合甲

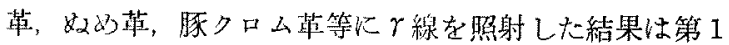

第 1 表 革に括よ゙す照射効果

\begin{tabular}{|c|c|c|c|c|c|c|}
\hline 革の種類 & $\begin{array}{l}\text { 照射線量 } \\
\left(\times 10^{6} r\right)\end{array}$ & $\begin{array}{c}\text { 引張強さ } \\
\left(\mathrm{kg} / \mathrm{mm}^{2}\right)\end{array}$ & $\begin{array}{l}\text { 伸び } \\
(\%)\end{array}$ & $\begin{array}{c}T_{S} \\
\left({ }^{\circ} \mathrm{C}\right)\end{array}$ & 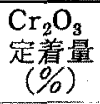 & $\begin{array}{l}+\infty \phi \\
L \% \\
(\%)\end{array}$ \\
\hline 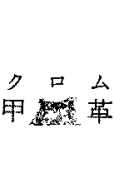 & $\begin{array}{r}0 \\
1 \\
2 \\
3 \\
5 \\
10\end{array}$ & $\begin{array}{l}2.44 \\
2.17 \\
2.15 \\
2.17 \\
1.83 \\
1.27\end{array}$ & $\begin{array}{l}63.3 \\
55.5 \\
62.9 \\
53.1 \\
60.9 \\
46.7\end{array}$ & $\begin{array}{c}\text { 100以上 } \\
95.1 \\
94.7 \\
92.3 \\
86.5 \\
80.2\end{array}$ & $\begin{array}{l}4.07 \\
4.09 \\
3.95 \\
3.91 \\
4.01 \\
4.03\end{array}$ & \\
\hline $\begin{array}{l}\text { タンン } \\
\text { 早 } \\
\text { 芇 }\end{array}$ & $\begin{array}{r}0 \\
1 \\
2 \\
3 \\
5 \\
10\end{array}$ & $\begin{array}{l}2.76 \\
2.73 \\
2.65 \\
2.54 \\
2.46 \\
2.32\end{array}$ & $\begin{array}{l}45.1 \\
50.9 \\
47.1 \\
49.6 \\
44.8 \\
54.2\end{array}$ & $\begin{array}{l}78.6 \\
78.0 \\
77.5 \\
76.6 \\
71.9 \\
71.0\end{array}$ & & 57.6 \\
\hline $\begin{array}{l}ク ロ ム ・ ~ \\
\text { タンニン } \\
\text { 複合甲革 }\end{array}$ & $\begin{array}{r}0 \\
1 \\
2 \\
3 \\
5 \\
10\end{array}$ & $\begin{array}{l}2.73 \\
3.14 \\
2.69 \\
2.89 \\
2.25 \\
2.05\end{array}$ & $\begin{array}{l}51.9 \\
44.7 \\
51.0 \\
49.4 \\
50.4 \\
44.5\end{array}$ & $\begin{array}{c}\text { 100以上 } \\
\prime \prime \\
\prime \prime \\
\prime \prime \\
96.0 \\
88.4\end{array}$ & $\begin{array}{l}2.64 \\
2.59 \\
2.62 \\
2.60 \\
2.58 \\
2.60\end{array}$ & 25.8 \\
\hline ぬ め 患 & $\begin{array}{l}0 \\
1 \\
2.5 \\
5.0 \\
7.5 \\
10\end{array}$ & $\begin{array}{l}2.89 \\
2.68 \\
2.77 \\
2.84 \\
2.68 \\
2.59\end{array}$ & $\begin{array}{l}41.4 \\
37.3 \\
40.8 \\
37.2 \\
36.3 \\
37.6\end{array}$ & $\begin{array}{l}80.2 \\
80.7 \\
81.5 \\
78.9 \\
78.3 \\
77.2\end{array}$ & & 65.0 \\
\hline 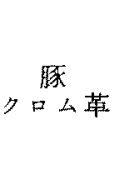 & $\begin{array}{r}0 \\
1 \\
2 \\
3 \\
5 \\
10\end{array}$ & $\begin{array}{l}1.71 \\
1.63 \\
1.37 \\
1.37 \\
1.14 \\
0.95\end{array}$ & $\begin{array}{l}38.3 \\
29.6 \\
33.2 \\
33.2 \\
33.7 \\
31.5\end{array}$ & $\begin{array}{c}100 \text { 以上 } \\
96.0 \\
94.2 \\
92.0 \\
85.5 \\
80.8\end{array}$ & $\begin{array}{l}3.22 \\
3.00 \\
2.96 \\
2.95 \\
2.37 \\
2.07\end{array}$ & \\
\hline
\end{tabular}

表の通りである.ここで 3 つの物理的性質の测定は前記

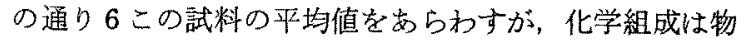
理試験測定後の切断試料片を細切し十分混合したすのを 供試した. $T_{S}$ の測定試料は物理試験前のダンベル型試 料の中央平行部を除く試料取付部より採取した。

草化 $\gamma$ 線を照射する場合, 引張強さ，伸びょよび $T_{S}$ はいずれも低下しいわゆる脆化をきたすが，その㑯向は 革の種類によって翼っている.ク口ムなめししたるのは 牛革女るい性豚草の上5に原皮の種類を問わず脆化し, その傾向がタンニンなめししたるのに比烄して大である。 供試革の引張強さの低下の順位は,

$$
\begin{aligned}
& \text { クロム甲革〉タロム タンンン複合甲革 }> \\
& \text { タンニン甲草>はめ草 }
\end{aligned}
$$

$T_{S}$ の低下の順位は引張強さの場合と同様な傾向を示 寸.

これらの物理的性質の低下の理論的意義伔つてては考 察の項にて論じたい。

\section{2. 革の化学組成におよぼす照射効果}

ここでは植物タンニン革を中心に皮革化学的組成，す 
第 2 表 タンニン革の化学組成におよほす照射効果

\begin{tabular}{|c|c|c|c|c|c|c|c|}
\hline の種類 & $\begin{array}{l}\text { 照射線量 } \\
\left(\times 10^{6} \mathrm{r}\right)\end{array}$ & $\begin{array}{l}\text { 水分 } \\
(\%)\end{array}$ & $\begin{array}{c}\text { 脂 肪 分 } \\
(\%)\end{array}$ & $\begin{array}{c}\text { 全 灭 分 } \\
(\%)\end{array}$ & $\begin{array}{c}\text { 可溶性成分 } \\
(\%)\end{array}$ & $\begin{array}{l}\text { 皮筫 } \\
(\%)\end{array}$ & $\begin{array}{l}\text { なめ } \\
\text { L度 } \\
(\%)\end{array}$ \\
\hline $\begin{array}{l}\text { タン }=\text { 革 } \\
\text { 甲 }\end{array}$ & $\begin{array}{r}0 \\
1 \\
5 \\
10\end{array}$ & $\begin{array}{l}13.9 \\
14.6 \\
13.9 \\
14.9\end{array}$ & $\begin{array}{l}13.5(31.1) \\
12.0(29.1) \\
13.2(31.0) \\
12.5(28.4)\end{array}$ & $\begin{array}{l}0.26(0 \\
0.27(0 \\
0.27(0 \\
0.28(0\end{array}$ & $\begin{array}{l}0.14 \\
5.23 \\
4.63\end{array}$ & $\begin{array}{l}43.3 \\
41.3 \\
42.5 \\
43.8\end{array}$ & $\begin{array}{l}57.6 \\
63.6 \\
59.3 \\
55.2\end{array}$ \\
\hline$=$ & $\begin{array}{r}0 \\
10\end{array}$ & $\begin{array}{l}16 . \\
16 .\end{array}$ & & $\begin{array}{l}0.14 \\
0.10\end{array}$ & & & $\begin{array}{l}65 . \\
59 .\end{array}$ \\
\hline
\end{tabular}

（）内の数字は(成分/皮留) $\times 100$ をあらすす。

なわち水分, 脂肪分, 可溶性成分, 皮質等の $r$ 線照射に よる影響をしらべた，タンニン甲革括よびねめ革に拉よ ぼす照射効果は第 2 表の通りである。

化学組成に与える照射効果浽第 2 表に明らかなように それ葟ど著しい程度ではないが，第 1 表に示されるよう に一般に革の抗張性が著しい効果を受ける $10^{7} \mathrm{r}$ の照射 の場合にはなめし度の低下が僅か認められる. 可溶性成 分（主として非タンニン）には汪とんど影響が認められ ない，皮質当りの脂肪量が $10^{7} \mathrm{r}$ の照射ではタンニン甲 革の場合 $2.7 \%$, 邓革の場合 $2.4 \%$ 減少している。な わし度は前者の場合 $2.4 \%$ ，後者の場合は $5.1 \%$ の減少 を示すが可溶性成分にはほとんど变化が見られないので なめし度の変動の起因が明確ではない。

\section{2. 植物タンニンにおよぼす照射効果}

皮革工前において一般になるし材料として使用される ミモザ,ケブラチョ峤よびチェストナットの3種のタン ニンエキスを供試した，前二者は縮合型ダンニンであり，

第 3 表 植物タンニンエキスに括上ぼす照射効果

1. Löwenthal 法

\begin{tabular}{|c|c|c|c|c|c|}
\hline $\begin{array}{l}\text { タンニン } \\
x \neq x\end{array}$ & & \multicolumn{2}{|c|}{ 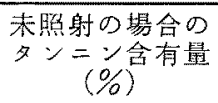 } & \multicolumn{2}{|c|}{$\begin{array}{l}5 \times 10^{6} \mathrm{r} \text { 照射した } \\
\text { 場合のタンンン含 } \\
\text { 有嘼 }(\%)\end{array}$} \\
\hline$€$ & $サ ゙$ & \multicolumn{2}{|c|}{56.5} & \multicolumn{2}{|c|}{55.6} \\
\hline ケブ & $\exists$ & \multicolumn{2}{|c|}{56.3} & \multicolumn{2}{|c|}{52.8} \\
\hline チェストナッ & r & \multicolumn{2}{|c|}{56.1} & \multicolumn{2}{|c|}{61.8} \\
\hline \multicolumn{6}{|c|}{ 2. 皮 粉 法 } \\
\hline \multicolumn{2}{|l|}{ タン $ン$} & \multicolumn{2}{|c|}{ 末照射の場合 } & \multicolumn{2}{|c|}{$\begin{array}{l}5 \times 10^{6} \mathrm{r} \text { 㠫射 } \\
\text { した場合 }\end{array}$} \\
\hline$I \neq x$ & & $\begin{array}{l}\text { タン } \\
\text { ソ分 }\end{array}$ & $\begin{array}{l}\text { 非タン } \\
=\text { ソ分 }\end{array}$ & $\begin{array}{l}\text { タン }= \\
\text { บ分 }\end{array}$ & $\begin{array}{l}\text { 非タン } \\
\text { ニン分 }\end{array}$ \\
\hline$\Sigma$ & $\ddot{H}$ & $\begin{array}{c}71.7 \\
(81.4)\end{array}$ & $\begin{array}{c}9.62 \\
(12.2)\end{array}$ & $\begin{array}{c}75.1 \\
(86.9)\end{array}$ & $\begin{array}{r}7.85 \\
(9.08)\end{array}$ \\
\hline ケブ テ & $\exists$ & $\begin{array}{c}69.2 \\
(80.3)\end{array}$ & $\begin{array}{c}13.5 \\
(15.8)\end{array}$ & $\begin{array}{c}69.6 \\
(81.4)\end{array}$ & $\begin{array}{r}7.70 \\
(9.01)\end{array}$ \\
\hline fェストナッ & $r$ & $\begin{array}{c}68.5 \\
(79.3)\end{array}$ & $\begin{array}{c}13.0 \\
(15.2)\end{array}$ & $\begin{array}{c}69.6 \\
(76.7)\end{array}$ & $\begin{array}{c}14.0 \\
(16.6)\end{array}$ \\
\hline
\end{tabular}

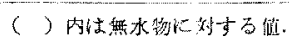

のと考兑られよ5。

後者は加水分解型タンニンであ. 万、照射線量は $5 \times 10^{6} \mathrm{r}$ であっ た. Löwenthal法抺よび皮粉法 で純タンニン分を測定した結果. は第 3 表に示主通りである。

タンニンに拉よぼす照射の効 果は雨法により測定した結果が 全く逆の関係を示すが、これは 酗分析法の本質的差異K与る

\section{3. タンニンの紫外部吸収曲線}

前記の 3 種類のタンニンの0.1\% 水溶液の吸収曲線か、 らタンニンが照射により受ける性状の変化をしらべた。 ミモザ,ケブラチョ拈よびチェストナットェチスの各溶 液について 300〜650 m $\mu$ の範团にわたりヘックマン分 光光度計により吸収曲線を求めた。毛れらの結果は第 1 因に示す通りである。

ミモザ括よびケブラチョ等の縮合型タンニンは未照射 の場合，極大吸収位置は 305 就よび $310 \mathrm{~m} \mu$ に亦るが， $5 \times 10^{6} \mathrm{r}$ 照射後は 310 扝よび $325 \mathrm{~m} \mu$ に移動し，かつ深 色効果学現わしているが，チェストナットエキスの場合

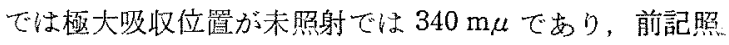
射後は $315 \mathrm{~m} \mu$ に移動しかつ浅色効果を現うしている。 縮合型タンニンでは極大吸収位置が長波長側へ移動し， からタンニン濃度の增大が認好られるが，加水分解型多

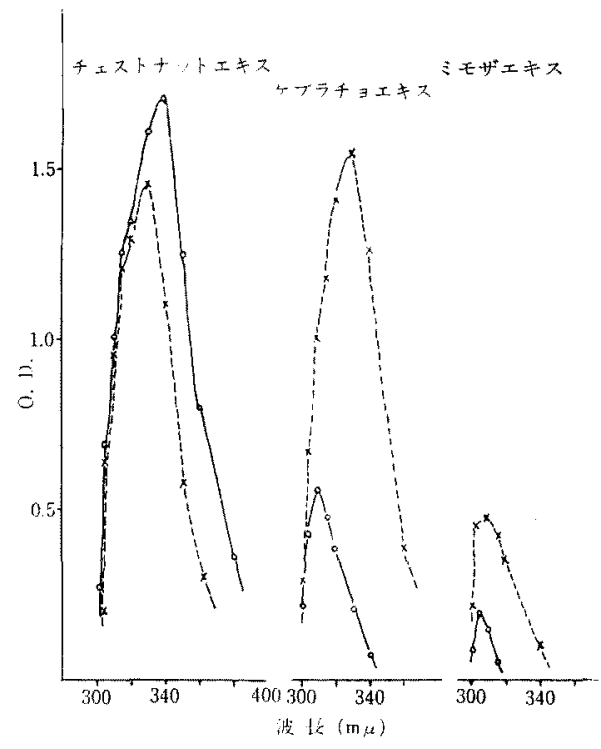

符 1 图植物タンニン溶液の吸収曲線 一O- 槛的 $\cdots \times \cdots 10^{7} \mathrm{r}$ 照射後 


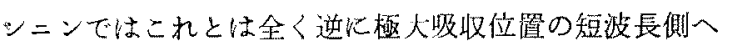
の移動ならびに潞度の低下が認められる。タンニンに拉 よばす照射効果については別の研究に扣いて詳細に取扱 5 予定である。

\section{4. クロム革の $\mathrm{Cr}_{2} \mathrm{O}_{3}$ 定若量と照射による脆化の関係}

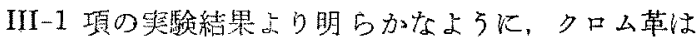
$10^{7} \mathrm{r}$ 程庭の血射に上り明瞭な脆化をきたす。タンニン 革ではク口ム革ほど著しい脆化性認められない，をこで

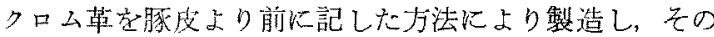

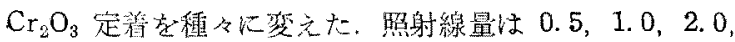

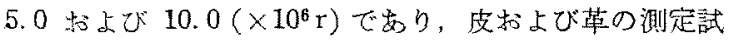

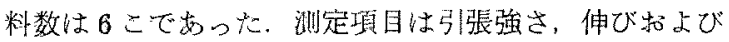
$T_{S}$ でる。生皮試料は脱灰，水洗後板張乾燥したもの のバット部より採取したものでかる。

笑験結果は第 4 裴に示す通りである。 また照射効果を

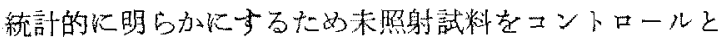

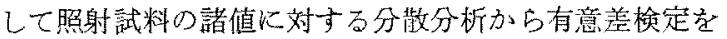
行なった結果必表中心記した。

未照射の場合を基準として引张強さ，伸びおよび $T_{S}$ の諸䛧を整理すれば，照射により諸量の低下の順位は次 のううになる。

引張強さ低下の覑位は，生皮， $\mathrm{Cr}_{2} \mathrm{O}_{3}$ 定着量 $0.48 \%<$ $\mathrm{Cr}_{2} \mathrm{O}_{3}$ 定着量 $0.94 \%<\mathrm{Cr}_{2} \mathrm{O}_{3}$ 定着量 $1.7 \%$ となり， $\mathrm{Cr}_{2} \mathrm{O}_{3}$

定着且の大なるほど脆化は著しく，定着量の少ないはぼ 著しくない。

伸びは引張強さほど顕著ではないので照射好果を傾向 づけることはもずかしい。

$T_{s}$ の低下の㟲位は生皮に効乙，照射線量加 $5 \times 10^{6} \mathrm{r}$ 以上になると $T_{S}$ か゚測定不能になる．何となれば水漬し た場合火膨潤状態となり，もはや顕著な蓺取紑現象圭呈 さなくなる。これは皮蛋白の微細構造の崩壊を意味する ことに外ならない，そこで $\mathrm{Cr}_{2} \mathrm{O}_{3}$ 定着軖の異なる革火対 与る照射发石 $T_{S}$ の低下の順位は，生皮> $\mathrm{Cr}_{2} \mathrm{O}_{3}$ 芷着 鼠 $0.47 \%>\mathrm{Cr}_{2} \mathrm{O}_{3}$ 定着舅 $0.94 \%>\mathrm{Cr}_{2} \mathrm{O}_{3}$ 定着量 $1.7 \%$ となり，引張強さ低下の順位と逆の関係にある。

照射効果火関与る有意性の㛟定結果は，クロム革中の $\mathrm{Cr}_{2} \mathrm{O}_{\mathrm{a}}$ 定着量が增すはど有意性が顕著になることを灾し ている、すなかり定着量が $0.48 \%$ の锡合には $10^{7} \mathrm{r} の$ 照射で有意性が認められるが，定着量が $0.94 \%$ 以上で は $5 \times 10^{6} \mathrm{r}$ の照射で有意となる。

伸びについては照射効果は不明確でする。

5. ホルムアルデヒド革におよぼす照射効果一ーホル マリン処理量と照射による脆化の関係

試料革の HCHO 定着量は測定して店いが，菂裸皮重 星（水分量 68.2\%) に刘してホルマリン溶液 (HCHO 紲

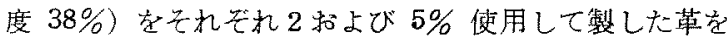
供試した。照射線量は III-4 項々同

第 4 表 $\mathrm{Cr}_{2} \mathrm{O}_{3}$ 定着䁷を罢に寸るク口ム革の物理的性貿に 扣上任与照射效果

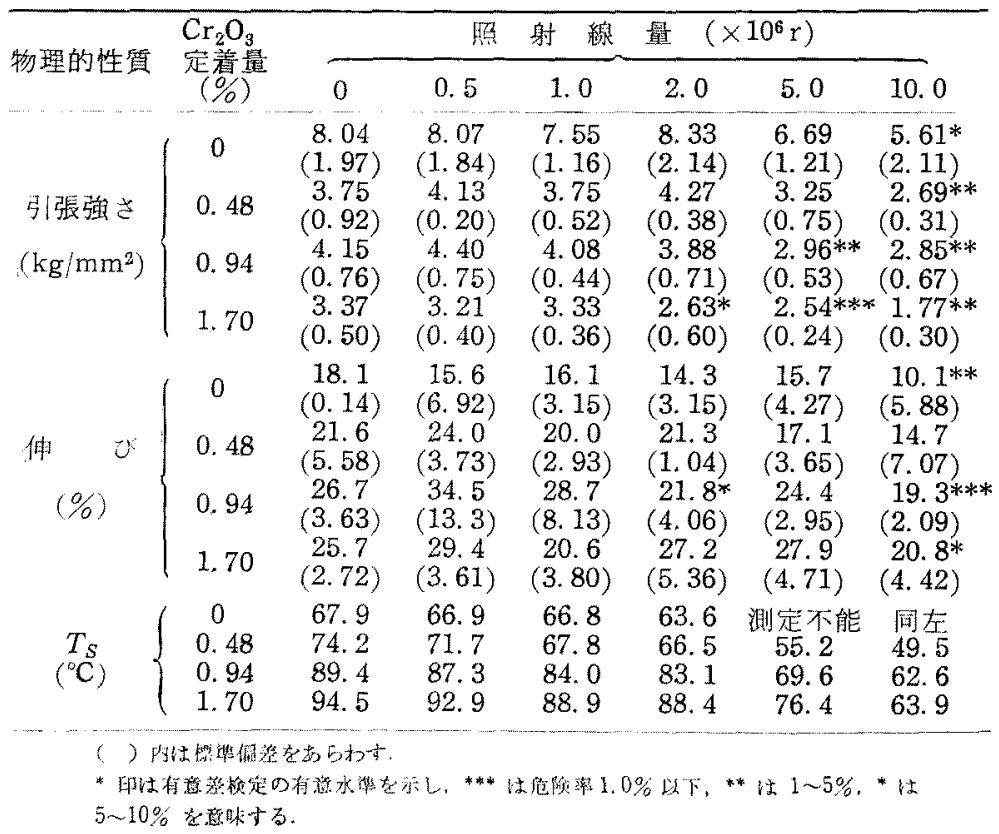

一であり，実䮖結果は第 5 表に示す。 ホルマリン未処理の生皮は前項の 实驗に竦いて使用されたすのと同じ である、実験絬果によれ佂 $5 \times 10^{6} \mathrm{r}$ 以上の照射線量では未照射試料比 校して弓張強さ，伸び拈よび $T_{S}$ 等 の低下することが楒められる。

引張強さの低下順位は，生皮く $2 \%$ 処婜試糊 $<5 \%$ 処理試料.

伸びの低下䫅位估前項の場合と同 様に照射效果を㑯向づけることはを ずかしい。

$T_{S}$ の低下の低下順位は，生皮> $2 \%$ 処理試料>5\% 処理試料.

$T_{S}$ の低下の順位は引涨強さ低下 の順位と逆の傾向を示すことはり口 ム革の場合と同様な関係にあること は興味樑い。 
第 5 表 ホルムアルデヒド革の物理的性質におよばす照射効果

\begin{tabular}{|c|c|c|c|c|c|c|c|}
\hline \multirow{2}{*}{ 物理的性質 } & \multirow{2}{*}{$\begin{array}{c}\text { ホルーリ } \\
\text { ン逃理量 } \\
(\%)\end{array}$} & \multicolumn{2}{|r|}{ 照 } & 射 線 & \multicolumn{2}{|c|}{ 量 $\left(\times 10^{6} \mathrm{r}\right)$} & \multirow[b]{2}{*}{10.0} \\
\hline & & 0 & 0.5 & 1.0 & 2.0 & 5.0 & \\
\hline $\begin{array}{c}\text { 引張強ざ } \\
\left(\mathrm{kg} / \mathrm{mm}^{2}\right)\end{array}$ & 2 & $\begin{array}{c}8.04 \\
(1.97) \\
4.01 \\
(0.64) \\
3.06 \\
(0.41)\end{array}$ & $\begin{array}{c}8.07 \\
(1.84) \\
3.94 \\
(0.68) \\
2.86 \\
(0.34)\end{array}$ & $\begin{array}{c}7.55 \\
(1.16) \\
3.89 \\
(0.44) \\
3.08 \\
(0.60)\end{array}$ & $\begin{array}{c}8.33 \\
(2.14) \\
3.33^{*} \\
(0.54) \\
2.70 \\
(0.46)\end{array}$ & $\begin{array}{c}6.69 \\
(1.21) \\
3.59 \\
(0.70) \\
2.32^{* * *} \\
(0.37)\end{array}$ & $\begin{array}{l}5.61 * \\
(2.11) \\
2.96^{* * * *} \\
(0.28) \\
2.06^{* * * *} \\
(0.41)\end{array}$ \\
\hline 伸 $(\%)^{ひ ゙}$ & 5 & $\begin{array}{c}18.1 \\
(0.14) \\
17.5 \\
(2.62) \\
22.8 \\
(8.80)\end{array}$ & $\begin{array}{c}15.6 \\
(6.92) \\
14.9 \\
(3.61) \\
2.44 \\
(7.15)\end{array}$ & $\begin{array}{c}16.1 \\
(3.15) \\
20.6 \\
(3.80) \\
16.7 \\
(8.63)\end{array}$ & $\begin{array}{c}14.3 \\
(3.15) \\
19.0 \\
(5.36) \\
15.4 \\
(4.67)\end{array}$ & $\begin{array}{c}15.7 \\
(4.27) \\
12.5^{*} \\
(4.71) \\
17.3 \\
(5.89)\end{array}$ & $\begin{array}{c}10.1^{* *} \\
(5.88) \\
14.7 \\
(4.42) \\
18.3 \\
(7.34)\end{array}$ \\
\hline $\begin{array}{c}T_{S} \\
\left({ }^{\circ} \mathrm{C}\right)\end{array}$ & $\begin{array}{l}0 \\
2 \\
5\end{array}$ & $\begin{array}{l}67.9 \\
76.1 \\
77.4\end{array}$ & $\begin{array}{l}66.9 \\
70.4 \\
76.1\end{array}$ & $\begin{array}{l}66.8 \\
69.8 \\
74.6\end{array}$ & $\begin{array}{l}63.6 \\
67.9 \\
72.6\end{array}$ & $\begin{array}{c}\text { 測定不能 } \\
58.7 \\
63.3\end{array}$ & $\begin{array}{l}\text { 同左 } \\
49.5 \\
50.0\end{array}$ \\
\hline
\end{tabular}

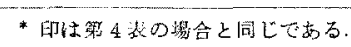

有意性の検定結果はないし処理が進む添ど $10^{7} \mathrm{r}$ で照 射効果は高度に有意であることを示しているが，伸びの 缶合は不明確である。

\section{6. 腱の微細構造におよぼす照射効果}

これまでの物理的諸性質に $\gamma$ 線は著しい效果を拉上活 すので微細構造の変化をX線回折法伛より調べた。試料 はカンガルー踛を使用し $10^{7} \mathrm{r}$ 照射したものと末照射試 料の回折図形を比孉した。実験は $\mathrm{CuK}_{2} の \mathrm{X}$ 線を健織細 軸に投射し $2 \theta$-回折線强度の関係を求妮ころ第 2 図 のような結果を得た。

実験結果によれば回折角 $2 \theta$ が $7^{\circ}$ および $19^{\circ}$ にピー クが現われ，7゚では鋭い山形となっているが $19^{\circ}$ の場

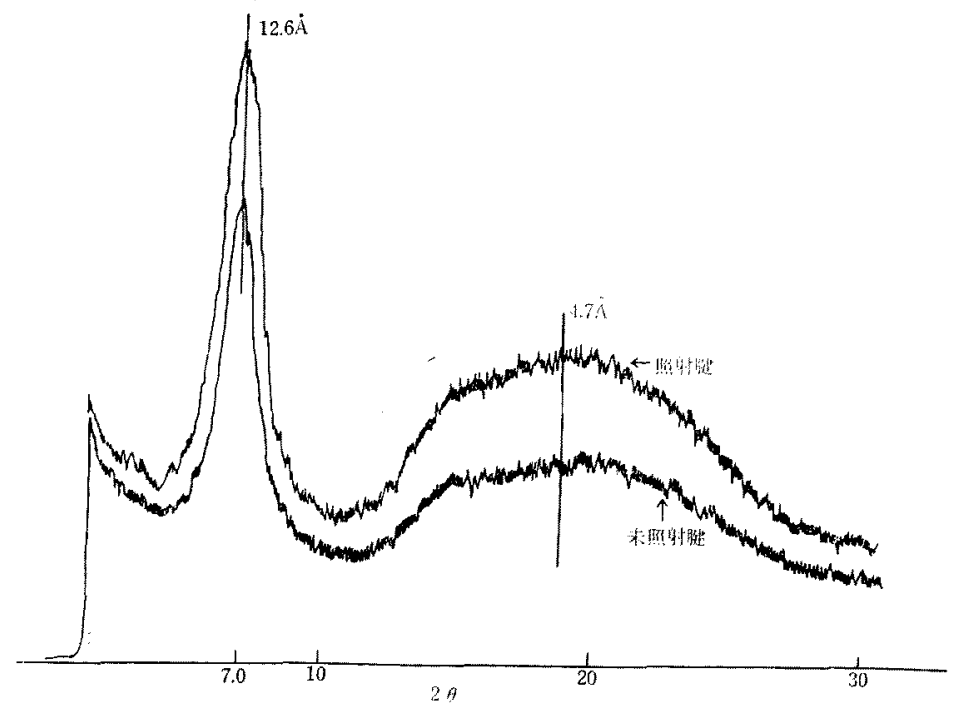

第 2 図カンガルー腱のX綜回折曲線
合はなだらかな丘形となっている。 $2 \theta$ の值から格子間䧣を算出すれば $12.6 \AA$ 拉よび $4.7 \AA$ となる。末照 射礼よび照射各試料は回折因におい て基本的差異はない，回折線の強度 に幾分の差異は認められるが，ピー クの位置倿化はないのであるから 広角回折領域に怙いて結晶榡造の全 面的崩壊あるい梳新しい結品構造の 発生ないしは転移の現象は認められ ない。

\section{4. 考察}

皮蛋白主要構成分であるコラーダ ンがミセル構造をなすことは以前よ り知られることであり，長鎖状蛋白分子は相互に水素結 合，イオン結合，極性結合等により架橋が形成されて拉 り，なぬしによりさらに二次的蛋白分子閒炕架橋が形 成され熱抵抗性を高める。Flory $5^{(5)}$ 性熱収縮過程を融 解現像として取扱い，(a) ポリペプチッド鎖閒の水素結 合の破壤，(b) 主ペプチッド鎖の分裂，(c) いわゆる塩 結合とよばれるアミノ酸残基の極性残基間静電結合の変 化等によって促進されるとしている。

Casse1(1)は低線量照射ではアミノ酸残基に対しごく僅 かしか変化を打上涪さないことをアミ/酸分析結果より 認め, 前記 (a) および (b) の現象が $2 \times 10^{7} \mathrm{rad}$ 以下 の照射の場合に支配的であるとしている，本報に晾惊る 夷験では最大照射でる107 $\mathrm{r}$ である から照射効果はコラーゲン構造の側 鎖吅よび主鎖に関するものとい光よ ラ、腱コラーゲンに対する照射線量 が $5 \times 10^{6}$ rですでに $T_{S}$ の測定が不 能になることを認めたが，Casselの 実験では $9 \times 10^{7} \mathrm{rad}$ の照射を行な った場合，䭈コラーダンは $1^{\circ}$ の水 浴中で $10 \mathrm{~g}$ の荷重を支持すること ができず破壊することを認めている。 Weir (6) (熱力学的考察を行ない, 熱収縮にともな5活性化定数を算出 しているが，この論文によれば常温 $25^{\circ}$ に执いて長さが半減する時間は 腱コラーダンの場合, $\mathrm{pH} 7.2$ 亿括

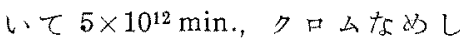


$3 \times 10^{17} \mathrm{~min}$, ホルムアルデヒドなめし $3 \times 10^{17} \mathrm{~min} . と$ なって拈り，なめし処理によりコラーゲンは熱的に安定 してくることがいえる， 子系のエネルキ゚ー位を活性化し分子間の架橋結合特よび 分子主鎖の切断を結果するが，ここ生成するフリーラ ジカルは近接する他のフリーラジカルと再結合するです ろう。たたし湿度の異なる空気中で照射した場合は， $T_{S}$ の低下に卧とんど差がないことからCassel はコラーゲ ン中に存在する水分子のフリーラジカルはたいした影響 を持たないと述べている。

またクロムあるいはタンニンのようななめし威がコラ ーダンの微細棈造に変化をもたらすか否かについては従

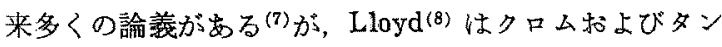
ニンなめし理諭の研究に秃いてないし成がコラーダンの $\mathrm{X}$ 線回折図形の赤道面スペーシング (側鎖閭隔) K変化 を与克，これが失われるかあるいは仿けてくる結果を認 めている，そこで本報り実駼結果（第 4 於よび5表）に よれば引張强さは生皮の方がなめし処理の進んだものに 比較して低下の程度が低いことは，なめし処理によりコ

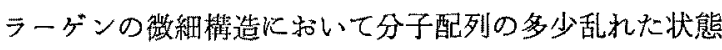
となり、これよりて線の影響を強く受的主鑜切断をさた すのであろ5。照射以前の状態に扔いてるなるて処理に より，皮の引張強さ藷しく低下るることから推察さ れる. 蛋白分子主鎖の切断はX線回折の結果加ら考㝋て

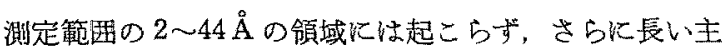

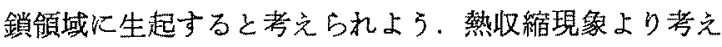
れば $T_{S}$ はコラーゲン分子間の架標度の一凡度と考克ら れるので 線はこの架语結合を切断する. 分子間の架橋

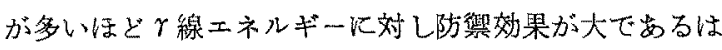
ずであるから本实駼結果の上うになめし処理が進む任 ど $T_{S}$ の低下の程度が小となることは当然である，ク口 ムなめしとホルムアルデヒドなめしはなめし機棈が暴な り、コラーゲンとなあし绪分子の結合が主として前者怔 イオン結合と配位結合に基つくくが後者は共有結合に基つ いていると考えられている ${ }^{(8)}$ 。このようになめし昘の絬 合様式の異なる両者の革が結合の切断に括いては著しい 差琵は認められない。

クロム甲革と植物タンニン革は照射の效果がかなり異

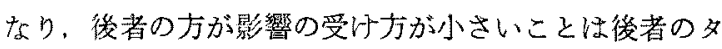
ンニンとコラーゲンの結合が多点結合 multipoint bind-

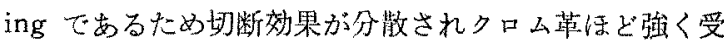

けないことによるのであろう。

\section{要 䄪}

皮特よびクロムなめし，植物タンニンなめし，ホルム アルデヒドなめし皮等に $\gamma$ 線を照射する場合 $10^{7} \mathrm{r}$ の照 射量火牤いて引張強さ，特よび熱收縮温度等の物理的性 質は著しい低下を認めることがでさるが，植物タンニン なめし皮（タンニン甲草およびめめ革）はり口ムなるし

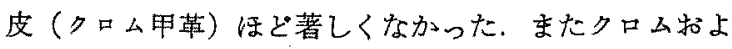
びホルムアルデヒドなめしにおいてなるし成の処理量を 種々に変壳て照射の影響を調べた結果によればなめし斉

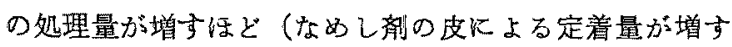
ほど）照射による引張強さ括よび伸び等の力学的性質の 低下，ななるら脆化が著しくなるが，これに反し熱収繀 温度すなわち熱的性質はなめし剤の処理量が增すにど照 射に対し幾分皮蛋白は安定化することが認められる。

磄コラーダンの微細構造に和よぼすと線の照射効果を

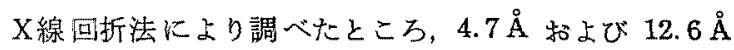
の位珇にスベーシングが現孙る。しかし $10^{7} \mathrm{r}$ 程度の 照射線量で结未照射試料と比較して赤道面のスペーシン グに変化を喆め得なかったので寒験回折領域（本害験で は2 $2 \theta: 2 \sim 40^{\circ}$ すなわら $44 \sim 2.25 \AA$ ) では微細構造の变 化をきたさなかったといるよう。

本研究を行な5に当りX線回折契験见種々便宜を賜わ った東京工業大学教授舟木好右衛門博士飞深是なる謝愙 を表する次第である。

(1) J. Cassel : J. Am. Leather Chem. Assoc., 54, 432 (1959).

(2) V.G. Velly, N. D. Gallagher, M.B. Neher : ibid., 55, 202 (1960).

(3) Löwenthal Method: "The Leather Chemists" Pocket Book", p. 204 (1937).

(4) "Official Methods of Analysis", p. 16(1951).

(5) P. Flory, R. Garret : J. Am. Chem. Soc., 80, 4836 (1958).

(6) C. E. Weir : J.Am. Leather Chem. Assoc., 44, 108 (1949).

(7) G. D. McLaughlin, E. R. Theis : "The Chemistry of Leather Manufacture", p. 494, 603 (1945).

(8) D. J.Lloyd : J. Intern. Soc. Leather Trades' Chem., 19, 336 (1935).

(9) G. D. McLaughlin, E. R. Theis : "The Chemistry of Leather Manufacture", p. 332, 539 (1945). 